\title{
RESPON PERTUMBUHAN TANAMAN SAWI PAGODA (Brassica narinosa L.) DENGAN SUBTITUSI POC SAMPAH RUMAH TANGGA SISTEM HIDROPONIK RAKIT APUNG
}

\section{RESPONSE TO GROWTH OF SAWI PAGODA PLANT (Brassica narirosa L.) WITH LOF SUBTITUTION WASTE HYDROPONIC SYSTEM OF FLOATING RAFT}

\author{
Inka Dahlianah ${ }^{1 *}$. Ita Emilia ${ }^{1}$, Rih Laksmi Utpalasri ${ }^{2}$ \\ ${ }^{1}$ Jurusan Biologi Fakultas Sains dan Teknologi Jl. A.Yani 9/10 Ulu Palembang \\ ${ }^{2}$ Jurusan Ilmu Perikanan Fakultas Perikanan dan Kelautan Jl. A.Yani 9/10 Ulu Palembang \\ *Email: inkadahlianahrohim@gmail.com \\ * Corresponding Author, Diterima: 7 Mar. 2021, Direvisi: 29 Mar. 2021, Disetujui: 24 Mei 2021
}

\begin{abstract}
Liquid Organic Fertilizer that are subtituted are one of the innovations that are carried out hydroponically. The purpose of Study was to obtain the correct percentage of liquid organic Fertilizer Substitution for Pagoda Mustard Plants. The study was conducted in September - November 2020. This study used a completely randomized design with one factor consisting of 5 treatments and 4 replications. The nutrient solution treatment factors were: N0: AB Mix 0\% + POC 100\%. N1: AB Mix 20\% + POC 80\%, N2: AB Mix 40\% + POC 60\%, N3: AB Mix 60\% + POC 40\%. N4: AB Mix 80\% + POC 20\% to obtain 20 treatment units, each treatment unit contains 3 plants, the total number of plants is 60 plants. Plant parameters are plant height $(\mathrm{cm})$, root length $(\mathrm{cm})$, and plant fresh weight $(\mathrm{g})$. Data were analyzed quantitatively with analysis of variance at alpha $5 \%$, to determine whether there was a significant difference between treatments. If there is a real difference, then test it by further testing the Least Significant Difference (LSD) at 5\% alpha. The results showed that the highest plant height was found in N4 treatment at N4 parameters of $11.50 \mathrm{~cm}$, the highest root length in $N 4$ treatment was $15.25 \mathrm{~cm}$, and the highest plant fresh weight was $149.75 \mathrm{~cm}$.
\end{abstract}

Keywords: Hydroponic, pagoda mustard, floating raft, substitution.

\begin{abstract}
ABSTRAK
Pupuk organik cair yang disubtitusi merupakan salah satu inovasi yang dilakukan secara hidroponik. Tujuan dari penelitian ini adalah untuk mendapatkan persentasi subtitusi pupuk organik cair yang tepat terhadap tanaman sawi pagoda. Penelitian telah dilakukan pada bulan September - November 2020. Penelitian ini menggunakan rancangan acak lengkap dengan satu faktor terdiri 5 perlakuan dan 4 ulangan. Faktor perlakuan larutan Nutrisi adalah: N0: AB Mix $0 \%+$ POC $100 \%$. N1: AB Mix $20 \%+$ POC $80 \%$, N2: AB Mix $40 \%+$ POC 60 $\%$, N3: AB Mix $60 \%+$ POC $40 \%$. N4:AB Mix 80\% + POC $20 \%$ sehingga diperoleh 20 unit perlakuan, setiap unit perlakuan berisi 3 tanaman, jumlah seluruh tanaman adalah 60 tanaman. Parameter tanaman adalah tinggi tanaman $(\mathrm{cm})$, panjang akar $(\mathrm{cm})$, dan bobot segar tanaman $(\mathrm{g})$. Data dianalisis secara kuantitatif dengan sidik ragam (analysis of variance) pada alpha $5 \%$, untuk mengetahui apakah ada beda nyata antar perlakuan.
\end{abstract}


Jika ada beda Nyata, di uji dengan uji lanjut Least Significant Difference (LSD) pada alpha $5 \%$. Hasil penelitian menunjukkan tinggi tanaman tertinggi terdapat pada perlakuan N4 pada parameter N4 sebesar 11,50 $\mathrm{cm}$, panjang akar tertinggi pada perlakuan N4 sebesar $15,25 \mathrm{~cm}$, dan berat segar tanaman tertinggi sebesar $149,75 \mathrm{~cm}$.

Kata kunci : Hidroponik, rakit apung, sawi pagoda, subtitusi.

\section{PENDAHULUAN}

Sawi pagoda (Brassica narinosa L.) marga brassica, memiliki daun berwarna sangat hijau sering disebut dengan istilah sayuran super green. Tanaman sawi sangat berpengaruh bagi kesehatan manusia, karena banyak mengandung nilai gizi yang sangat bermanfaat bagi tubuh. Sesuai dengan Direktorat Gizi, (2019) bahwa kandungan gizi setiap 100 g sayuran sawi adalah kalori $22,00 \mathrm{~K}$, protein 2,30 g, lemak 0,30 g, karbohidrat 4,00 g, serat 1,20 g, kalsium 220, 50 $\mathrm{mg}$, fosfor 38,40 mg, besi 2,90 mg, vitamin A 969,00 SI, vitamin $B_{1} 0,09 \mathrm{mg}, B_{2} 0,10 \mathrm{mg}, B_{3} 0,70 \mathrm{mg}$, vitamin C 102,00 mg. Tanaman sawi pagoda kalah populer dibandingkan jenis sawi lain yang terdapat dipasararan, baik pasar tradisional maupun pasar swalayan. Namun demikian sawi pagoda ini mulai digemarioleh masyarakat selain nilai gizi, sawi pagoda lebih enak dan renyah. karena itu perlu adanya usaha untuk lebih memperkenalkan tanaman ini. Salah satu usaha yaitu dengan penanaman sawi pagoda, dengan cara mensubtitusi pupuk organik cair berbahan baku sampah rumah tangga dengan sistem hidroponik. Penelitian ini dilaksanakan untuk melihat pengaruh nutrisi hidroponik yang disubtitusi dengan pupuk organik cair akan berpengaruh lebih baik terhadap pertumbuhan tanaman sawi pagoda.

Keuntungan bertanam secara hidroponik dibandingkan dengan cara konvensional jauh lebih tinggi, penanaman secara hidroponik tidak tergantung musim, tidak memerlukan lahan yang luas, hasil sayuran bebas pestisida, dalam pengendalian hama dan penyakit tidak menggunakan zat kimia, kualitas sangat baik, tenaga kerja yang diperlukan tidak banyak.

Sistem hidroponik merupakan sistem bercocok tanam tanpa menggunakan tanah, sehingga memiliki beberapa kelebihan. Sesuai dengan pendapat Ullah, et al (2019) bahwa penggunaan nutrisi mineral kedalam pelarut air adalah sebagai pengganti media tanah. Ada beberapa kelemahan dari sistem bertanam hidroponik yaitu harga nutrisi hidroponik lebih mahal sehingga dapat memperbesar biaya produksi secara keseluruhan, dampaknya harga jual sayur hiroponik lebih mahal dibandingkan dengan cara konvensional. Permasalahan lain pada sistem hidroponik adalah nutrisi yang biasa digunakan untuk bertanam hidroponik adalah dari bahan anorganik, kelemahan zat anorganik akan meninggalkan residu pada tanaman, berdampak negatif bagi kesehatan serta tidak ramah lingkungan, sedangkan. kelebihan nutrisi anorganik atau $\mathrm{AB}$ mix adalah tepat nutrisi, tepat ukuran/terukur, tepat peruntukan. Kelebihan nutrisi bahan organik harga lebih murah, tidak meninggalkan residu, bahan baku berlimpah, tidak berdampak bagi kesehatan serta ramah lingkungan.

Usaha mengeliminir mahalnya nutrisi dan residu nutrisi anorganik maka perlu adanya inovasi yaitu 
dengan mensubtitusi pupuk organik cair disingkat dengan POC kedalam pelarut air. Penelitian ini menggunakan sampah atau limbah rumah tangga. Sampah tersebut berupa sayuran hijau, kulit buahbuahan kulit pisang, pepaya, nanas, sabut kelapa, cangkang telur, limbah ikan, limbah udang, rerumputan hijau, daun kering, air kelapa, air leri, bonggol pisang. Sampah organik biasanya terdiri dari limbah tumbuhtumbuhan, dan hewan. Hal ini dilakukan sebagai alternatif untuk menekan biaya, bahwa menanam sayuran dengan sistem hidroponik bisa menggunakan nutrisi dari berbagai sumber. Menurut Darwis et al, (2013) pengertian organik artinya sumber bahan baku untuk pembuatannya berasal dari makhluk hidup yang ada baik hewan maupun tumbuhan. Didukung oleh pernyataan Ullah et al, (2019), pada sistem hidroponik, sumber nutrisi yang digunakan tidak terbatas hanya dari satu sumber, akan tetapi hasil samping berupa kotoran hewan maupun kimia bisa digunakan. Penambahan air kelapa, air leri, dan bonggol pisang pada proses pembuatan pupuk cair, memberikan manfaat yang sangat baik bagi tanaman karena mengandung zat pengatur tumbuh alami, dan vitamin selain unsur hara yang terkandung dalam POC. Sesuai dengan pendapat Rosniawaty et al, (2018), menyatakan air kelapa mengandung zat pengatur tumbuh IAA $0,0039 \%$, GA3 0,0018\%, sitokinin $0,0017 \%$, kinetin $0,0053 \%$ dan zeatin sebesar 0,0019\%. Lebih lanjut menurut Lalla, (2018) Air leri mengandung Vitamin B $80 \%$, Vitamin $\mathrm{B}_{3} 70 \%$, Vitamin $\mathrm{B}_{6} 90 \%$ mangan $50 \%$, Fosfor 50 $\%$, zat besi $60 \%$ dan dan menurut Lindung (2014) bonggol pisang mengandung zat pengatur tumbuh alami yaitu sitokinin eksogen, dimanfaatkan bagi tanaman untuk pertumbuhannya. Penggunaan zpt alami merupakan alternatif yang mudah diperoleh, murah dan aman digunakan.

Salah satu teknik memanfaatkan sampah organik yaitu dengan cara melakukan inovasi yaitu dengan cara mengolah sampah organik menjadi pupuk atau nutrisi bagi tanaman. Sampah ini menjadi bahan baku pembuatan pupuk organik cair, karena jauh lebih murah dan tidak ada dampak negatif atau residu yang tersisa baik pada tanaman, konsumen yang mengkonsumsi maupun lingkungan. Kandungan yang terdapat pada pupuk cair berbahan baku sampah diperlukan untuk pertumbuhan tanaman.

Sesuai dengan pendapat Jayati et al, (2019), penggunaan pupuk organik cair limbah sayur dapat meningkatkan bobot basah sawi pagoda yang lebih tinggi dibandingkan dengan perlakuan pupuk organik cair eceng gondok. Lebih lanjut menurut Oviyanti, (2016) bahwa daun gamal sebagai bahan baku pupuk organik cair yang diberikan berpengaruh sangat signifikan terhadap pertumbuhan tanaman sawi.

Tujuan dari penelitian ini adalah untuk mendapatkan persentase subtitusi pupuk organik cair yang tepat terhadap pertumbuhan tanaman sawi pagoda.

\section{BAHAN DAN METODE}

Penelitian ini telah dilaksanakan di lahan kebun Jalan Sukakarya Sukarami Palembang Sumatera Selatan, pada bulan September - November 2020.

Alat yang digunakan adalah ember, styrofoam box, tray semai, pisau, gunting, cutter, TDS meter, $\mathrm{pH}$ meter, lilin, gelas ukur, pinset, kawat, rockwool, penggaris, timbangan digital, speed, gergaji, paku, 
netpot ukuran $5 \mathrm{~cm}$, wadah komposter, sekop, penyaring, wadah derijen, double tape.

Bahan yang digunakan benih sawi pagoda standar pemerintah, air sumur/pam, plastik UV, Pelastik biasa warna silver. bambu, bioaktivator EM4, bungkus plastik. Penelitian ini menggunakan rancangan acak lengkap, karena kondisi penelitian terkendali dan homogen dengan faktor tunggal terdiri dari 5 perlakuan dan 4 ulangan. Faktor perlakuan larutan Nutrisi adalah:

N0: AB Mix $0 \%+$ POC $100 \%$, N1:AB Mix $20 \%+$ POC $80 \%$, N2: AB Mix $40 \%+$ POC 60 $\%$, N3: AB Mix $60 \%+$ POC $40 \%$, N4: AB Mix 80 $\%+$ POC $20 \%$. Total unit perlakuan yang diperoleh adalah 20 unit, setiap unit perlakuan berisi 3 tanaman, jumlah seluruh tanaman adalah 60 tanaman.

Parameter yang diamati adalah tinggi tanaman (cm), panjang akar $(\mathrm{cm})$, berat segar tanaman $(\mathrm{g})$ dihitung pada akhir penelitian.
Data hasil penelitian dianalisis secara kuantitatif dengan sidik ragam (analysis of variance) pada alpha $5 \%$, untuk mengetahui apakah ada beda nyata antar perlakuan. Jika ada beda Nyata, di uji dengan uji lanjut Least Significant Difference (LSD) pada alpha $5 \%$ (Gomez and Gomez, 1978).

\section{HASIL DAN PEMBAHASAN}

Hasil penelitian menunjukkan bahwa subtitusi dengan pupuk organik cair berpengaruh sangat nyata terhadap semua parameter (Tabel 1). Secara umum semakin turun persentase subtitusi Pupuk organik cair maka akan meningkatkan pertumbuhan tanaman sawi pagoda.

Tabel 2. Pada taraf $5 \%$ subtitusi pupuk organik cair terhadap tinggi tanaman pada perlakuan $\mathrm{AB}$ Mix $80 \%+20 \%(\mathrm{~N} 4)$ berbeda nyata dengan perlakuan AB Mix 60\%+POC 40\% (N3), AB Mix 40\%+ POC $60 \%(\mathrm{~N} 2)$, AB Mix 20\% + POC $80 \%(\mathrm{~N} 1)$, dan AB

Tabel 1. Hasil analisis sidik ragam subtitusi pupuk organik cair(POC) terhadap parameter tinggi tanaman, panjang akar dan bobot segar tanaman dengan Metode hidroponik dengan sistem Rakit Apung

\begin{tabular}{lcc}
\hline \multicolumn{1}{c}{ Peubah yang diamati $\%$} & Nutrisi Hidroponik & KK \\
\hline Tinggi Tanaman & $* *$ & 0,12 \\
Panjang Akar & $* *$ & 3,17 \\
Bobot Segar Tanaman & $* *$ & 6,21 \\
\hline
\end{tabular}

Tabel 2. Rerata tinggi tanaman (cm) terhadap subtitusi pupuk organik cair (POC) sampah rumah tangga terhadap tanaman sawi pagoda

\begin{tabular}{|c|c|c|}
\hline \multicolumn{2}{|c|}{ Perlakuan } & \multirow{2}{*}{$\frac{\text { Rerata Tinggi Tanaman Sawi Pagoda }(\mathrm{cm})}{06,00^{\mathrm{a}}}$} \\
\hline N0: AB Mix & $0 \%+$ POC $100 \%$ & \\
\hline N1: AB Mix & $20 \%+$ POC $80 \%$ & $07,50^{\mathrm{b}}$ \\
\hline N2: AB Mix & $40 \%+$ POC $60 \%$ & $07,80^{\mathrm{b}}$ \\
\hline N3: AB Mix & $60 \%+$ POC $40 \%$ & $08,75 \mathrm{~b}$ \\
\hline N4: AB Mix & $80 \%+$ POC $20 \%$ & $11,50 \mathrm{c}$ \\
\hline
\end{tabular}

BNT $5 \%=1,47$

Keterangan: Angka-angka yang diikuti huruf yang sama berarti berbeda tidak nyata $(5 \%)$ 
Mix $80 \%$ + POC $20 \%$ (N4) berbeda sangat nyata dengan perlakuan AB Mix $0 \%$ + POC 100\% (N0).

Dari hasil penelitian menunjukkan hasil tertinggi pada parameter tinggi tanaman pagoda, diduga bahwa subtitusi POC berada dalam keadaan yang tepat. Kandungan unsur hara dan adanya zpt alami dari air kelapa, bonggol pisang, dan vitamin $\mathrm{B}$ dari air leri yang terkandung pada pupuk organik cair (POC) berada dalam keadaan seimbang, dan tersedia bagi tanaman sehingga dapat mempengaruhi pertumbuhan tanaman. Kelebihan Pupuk organik sebagai nutrisi adalah dapat memperbaiki daya tahan tanaman, memiliki sifat positif terhadap serangan penyakit, tidak meninggalkan residu, sedangkan kandungan nutrisi anorganik AB Mix memiliki keunggulan yaitu memiliki unsur hara yang lengkap dan terukur sesuai dengan kebutuhan dari masing-masing jenis tanaman, keadaan ini akan mempengaruhi proses fisiologi tananaman dalam kegiatan pembelahan sel dan perpanjangan sel. Menurut Dahlianah, et al, (2020) bahwa tinggi tanaman dipengaruhi oleh proses pembelahan dan perpanjangan sel secara maksimal sehingga terjadi pertambahan tinggi pada tanaman. IAA dan sitokinin yang terdapat pada air kelapa dan sitokinin pada bonggol pisang berperan dalam pembelahan dan diferensiasi sel. Menurut pendapat Werner et al, (2001) pembelahan sel dan diferensiasi jaringan tertentu adalah peran dari sitokinin dan auksin yang bekerja sama terutaman dalam pembentukan tunas pucuk dan pertumbuhan akar. Kandungan vitamin B1 yang terdapat pada air leri dapat mempengaruhi respirasi dan fotosintesis tanaman. Koordinasi aktif respirasi dan fotosisntesa serta kontrol karbon dalam sel tumbuhan terlaksana akibat peran dari vitamin B (Fitz Patrick et al, 2020).

Rendahnya tinggi tanaman pada persentase POC yang tinggi diduga bahwa nutrisi/unsur hara, air, dan oksigen tidak cukup tersedia untuk pertumbuhan tanaman sawi pagoda, menyebabkan pertumbuhan tinggi tanaman tidak optimal. Sesuai dengan pendapat Parks et al, (2011), menyatakan bahwa nutrisi, air dan oksigen yang cukup sangat dibutuhkan dalam proses pertumbuhan tanaman..

Tabel 3. Pada taraf 5\% subtitusi pupuk organik cair terhadap panjang akar pada perlakuan.AB Mix $80 \%+$ POC $20 \%$ (N4) berbeda nyata dengan perlakuan AB Mix $60 \%+$ POC $40 \%$ (N3), AB Mix

Tabel 3. Rerata panjang akar tanaman sawi pagoda (g) terhadap Subtitusi pupuk Organik cair (POC) sampah rumah tangga terhadap tanaman sawi pagoda

\begin{tabular}{|c|c|c|}
\hline \multicolumn{2}{|c|}{ Perlakuan } & Rerata Panjang Akar Tanaman $(\mathrm{cm})$ Sawi Pagoda \\
\hline N0: AB Mix & $0 \%+$ POC $100 \%$ & $13,75^{\mathrm{a}}$ \\
\hline N1: AB Mix & $20 \%+$ POC $80 \%$ & $14,00^{\mathrm{b}}$ \\
\hline N2: AB Mix & $40 \%+$ POC $60 \%$ & $14,50^{\mathrm{c}}$ \\
\hline N3: AB Mix & $60 \%+\mathrm{POC} \quad 40 \%$ & $15,00^{\mathrm{d}}$ \\
\hline N4: AB Mix & $80 \%+$ POC $20 \%$ & $15,25^{\mathrm{e}}$ \\
\hline
\end{tabular}

BNT $5 \%=0,21$

Keterangan: Angka-angka yang diikuti huruf yang sama berarti berbeda tidak nyata ( $5 \%)$ 
$60 \%+$ POC $40 \%$ (N3) berbeda nyata dengan AB Mix $40 \%+$ POC $60 \%(N 2)$, AB Mix $40 \%+$ POC $60 \%$ (N2) berbeda nyata dengan AB Mix $20 \%+$ POC $80 \%(\mathrm{~N} 1)$, dan AB Mix $20 \%$ + POC $80 \%$ (N1) berbeda nyata dengan perlakuan AB Mix $0 \%+$ POC $100 \%$ (N0).

Perlakuan terbaik pada parameter panjang akar diduga cukupnya oksigen didaerah perakaran, menurut Dahlianah, et al (2020), bahwa panjang akar berhubungan erat dengan oksigen yang berada dalam keadaan cukup, sehingga proses aerasi akan berjalan dengan baik. Selain itu itu diduga vitamin $B_{1}$ yang terdapat pada air leri mempengaruhi pertumbuhan dan perkembangan tanaman. Sesuai dengan pendapat Lalla, (2018) menyatakan pertumbuhan berbagai jenis tanaman dapat dipengaruhi oleh air cucian beras. Selain itu diduga bahwa media tempat tumbuhnya akar yaitu larutan nutrisi sistem pada hidroponik tidak pada kondisi optimal, yaitu kondisi larutan unsur hara belum berada pada dosis yang sesuai bagi tanaman yang menyebabkan sistem perakaran tidak tumbuh dengan maksimal. Sesuai dengan pendapat Lakitan, (2011), bahwa sistem perakaran akan menyimpang pertumbuhannya dari kondisi idealnya, jika keadaan pada tempat tumbuhmya tidak pada kondisi yang sangat baik, namun apabila terjadi kebalikannya di pastikan sistem perakaran tanaman sepenuhnya baik, selain dari faktor genetik tanaman itu sendiri.

Tabel 4. Pada taraf 5\% subtitusi pupuk organik cair terhadap berat basah tanaman AB Mix $80 \%+$ POC $20 \%$ (N4) berbeda nyata dengan AB Mix $60 \%$ + POC $40 \%(\mathrm{~N} 3)$, AB Mix $40 \%$ + POC $60 \%(\mathrm{~N} 2)$, AB Mix $20 \%+$ POC $80 \%(N 1)$, dan AB Mix $80 \%$ + POC $20 \%$ (N4) berbeda sangat nyata dengan AB Mix $0 \%+$ POC $100 \%$ (N0).

Perlakuan subtitusi POC pada parameter bobot segar tanaman yang tinggi, diduga bahwa bobot segar sawi pagoda ditunjang oleh bagian vegetatif diatas tanaman seperti daun yang tumbuh dengan sangat baik, dan banyaknya kandungan air pada tanaman, selain dipengaruhi oleh pemberian nutrisi dan pengaruh zat pengatur tumbuh seperti sitokinin, dan auxin alami yang diperoleh dari air kelapa yang ditambahkan ke dalam pembuatan POC sehingga memacu pertumbuhan bobot segar tanaman, zat pengatur tumbuh ini akan berfungsi memacu pembelahan, perpanjangan dan pembesaran

Tabel 4. Rerata bobot segar tanaman sawi pagoda (g) terhadap pupuk organikcair(POC) sampah rumah tangga tanaman sawi pagoda

\begin{tabular}{|c|c|}
\hline Perlakuan & Rerata Bobot Segar Tanaman Sawi Pagoda \\
\hline N0: AB Mix $\quad 0 \%+$ POC $100 \%$ & $144,00^{\mathrm{a}}$ \\
\hline $20 \%+\mathrm{POC} \quad 80 \%$ & $145,50^{\mathrm{b}}$ \\
\hline N2: AB Mix $\quad 40 \%+$ POC $\quad 60 \%$ & $145,50^{b}$ \\
\hline $60 \%+\mathrm{POC} \quad 40 \%$ & $145,80^{b}$ \\
\hline $80 \%+$ POC $20 \%$ & $149,75^{\mathrm{c}}$ \\
\hline
\end{tabular}

Keterangan: Angka-angka yang diikuti huruf yang sama berarti berbeda tidak nyata (5\%) 
sel-sel dalam jaringan meristematik yang mengakibatkan bobot tanaman semakin naik. Proses pembelahan, perpanjangan dan pembesaran sel berkolerasi positif dengan bobot segar tanaman. Sesuai dengan pendapat George et al, (2008) bahwa pertumbuhan tunas dipacu oleh hormon sitokinin, sitokinin berperan dalam aktivasi pembelahan sel. Penyerapan unsur hara oleh akar tanaman yang sangat baik menyebabkan proses fotosintesa berjalan lancar maka bobot segar tanaman sawi pagoda akan lebih tinggi, lebih lanjut diduga bertambahnya bobot segar dikarenakan protoplasma tanaman sawi berfungsi dengan baik dalam menyimpan air dan CO. Sesuai dengan pendapat, Jayati, et al, (2019), bahwa berat tanaman yang meningkat dikarenakan tanaman mengandung protoplasma yang berfungsi sebagai tempat penyimpanan air dan $\mathrm{CO}$, dengan diikatnya air oleh protoplasma maka bobot segar tanaman akan naik seperti diperlihatkan pada perlakuan N4.

Rendahnya bobot segar tanaman pagoda, diduga untuk mendapatkan bobot segar yang optimal diperlukan unsur hara yang seimbang dan tepat dengan yang dibutuhkan oleh tanaman, kurangmya kebutuhan unsur hara pada tanaman ini, memungkinkan berpengaruh pada pertumbuhan dan perkembangan tanaman sehingga bobot segar sebagai hasil akhir menjadi tidak optimal, selain itu pemberian air kelapa, air leri, yang mengandung zat pengatur tumbuh alami sitokinin dan auksin dan vitamin $B_{1}$ berada pada konsentrasi belum tepat, akibatnya bobot segar yang diperoleh tidak maksimal, diduga zpt alami dan vitamin
$\mathrm{B}_{1}$ yang diberikan belum mampu mempengaruhi pertumbuhan tanaman karena proses fisiologi pembelahan dan perpanjangan sel belum sempurna, sehingga bobot segar yang diperoleh rendah. Sesuai dengan pendapat Mubarok et al, (2012), yang menyatakan bahwa zpt sitokinin sangat berperan dalam proses pembelahan sel pada bagian meristematik. Ada beberapa faktor yang mempengaruhi pemberian zpt alami pada tanaman, diantaranya jenis zpt yang diberikan, karena fungsi zpt berbeda-beda, fase tumbuh tanaman, dan konsentrasi zpt itu sendiri.

\section{KESIMPULAN}

Dari hasil pelitian dapat disimpulkan bahwa: Perlakuan subtitusi pupuk cair organik (POC) $80 \%$ $\mathrm{AB}$ mix + POC $20 \%(\mathrm{~N} 4)$ memberikan hasil tertinggi pada parameter tinggi tanaman sebesar $11,50 \mathrm{~cm}$, panjang akar sebesar 15,25, dan bobot segar tanaman sebesar 149,75 g. Sebaliknya perlakuan subtitusi pupuk organik cair (POC) $0 \%$ AB mix dengan 100\% POC (N0) memberikan hasil terendah pada parameter tinggi tanaman sebesar $06,00 \mathrm{~cm}$, panjang akar sebesar $13,75 \mathrm{~cm}$, dan parameter bobot segar tanaman sebesar 144, $00 \mathrm{~g}$.

\section{UCAPAN TERIMA KASH}

Tim Penulis mengucapkan terimakasih kepada Kepala LPPKM beserta semua jajaran, atas segala dukungannya, dan Universitas PGRI Palembang yang telah mendanai penelitian tahun 2020 . 


\section{DAFTAR PUSTAKA}

Dahlianah, I., Arwinsyah.,. Pebriana., K.S. Suhal, N.R. 2020. Tanggap Pertumbuhan dan Hasil Tanaman Sawi Pagoda (Brassica narirosa) terhadap berbagai Dosis Nutrisi AB Mix Metode Hidroponik dengan sistem Rakit Apung. Jurnal Sainmatika 17 (1): 55-60.

Darwis, Valeriana., Benny Rachman. 2013. Potensi Pengembangan Pupuk Organik In Situ Mendukung Percepatan Pertanian Organik. Forum Penelitian Agro Ekonomi. 31 (1): 51-65.

Fitz Patrick, T. and Chapman L.M. 2020. The Importance of Thiamin (Vit $\mathrm{B}_{1}$ ) in Plant Health: From Crop Yield to Biofartification. Journal of Biological Chemistry. 295 (34): 12002-12013.

Lalla, M. 2018. Potensi Air Cucian Beras sebagai Pupuk Organik pada Tanaman Seledri (Apium graveolus). Jurnal Agropolitan. 5 (1): 38-48.

Mubarok, Salamah. S., Farida, A., Rochayat, Y., dan Setiati, Y. 2012. Pengaruh kombinasi komposisi Media Tanaman dan Konsentrasi Sitokinin terhadap Pertumbuhan Aqlonema. Jurnal Hort. 22(3): 251-257.

Oviyanti, F., Syarifah., Nurul Hidayah. 2016. Pengaruh Pemberian Pupuk Organik Cair Daun Gamal ( Gliricidia sepium (Jacq.) Kunth ex Walp) terhadap Pertumbuhan Tanaman Sawi (Brassica juncea L.). Jurnal Biota. 2(1):61-67.

Gomez, K.A and Gomez,. A.A. 1978. Statistical Procedure for Agricultural Research. Second Edition. AWiley-Interscience Publication. John Wiley \& Sons. Inc. New York. 690 p.
George, E.F., Hall, M.A., \& De Klerk, G.J. 2008. Plant Propagation by Tissue culture, (third Edit). Springer. 503 p.

Irmawati. 2018. Respon pertumbuhan dan Produksi tanaman caisin (Brassica juncea L.) dengan Perlakuan Jarak Tanam. Journal of Agritech Science. 2 (1): 30-36.

Jayati, R.D., Ivoni, S, 2019. Perbedaan Pertumbuhan dan Produktivitas Tanaman Sawi Pagoda Menggunakan Pupuk Organik Cair dari Eceng Gondok dan Limbah Sayur. Jurnal Biosilampari. Jurnal Biologi. 1 (2): 73-77.

Parks, S., C Murray. 2011. Leafy Asean Vegetables and Their Nutrion in Hydroponics. State of New South Wales Australian. 24 p.

Rosniaty, S. I.R.D. Anjarsari, dan R. Sudirja. 2018. Aplikasi Sitokinin untuk Meningkatkan Pertumbuhan Tanaman teh di Dataran Rendah. J Tanaman Penyegar dan Industri. 5 (1):31-38.

Ullah, A., Aktar, S., Sutar, N., Kabir, R and Hossain, A. 2019. Cost effective Smart Hydroponic Monitoring and controlling system Using IoT. Journal of Intelligent Control and Automation 10 (4 ):142-154 p.

Werner.,. Motyka, V., Strnad, M and T. Schmulling. 20021. Regulat Ion Of Plant Growth by Cytokinin. Journal Proc Natt Acad Sci USA. 98(18): 10487-10492. 